\title{
Financial and Economic Impact of Brexit and COVID-19 in the United Kingdom
}

\author{
Darina SAXUNOVA ${ }^{1}$, Corlise LiesI LE ROUX² AND Manuel OSTER ${ }^{3}$ \\ ${ }^{1,3}$ Comenius University Faculty of Management, Bratislava, Slovakia \\ ${ }^{2}$ American University in the Emirates, Dubai, UAE
}

Correspondence should be addressed to: Darina SAXUNOVA; darina.saxunova@fm.uniba.sk

Received date:30 September 2019; Accepted date:18 September 2021; Published date: 16 February 2022

Academic Editor: Bodislav Dumitru Alexandru

Copyright (C) 2022. Darina SAXUNOVA, Corlise LiesI LE ROUX AND Manuel OSTER. Distributed under Creative Commons Attribution 4.0 International CC-BY 4.0

\begin{abstract}
Covid-19 struck a hard blow to the globalisation process that has been preparing for reconstructional changes since the Brexit issue has become a reality. As the Brexit negotiations were not finalised in a predetermined time range, the United Kingdom had to face the desired reality and cope with the situation hardened by the EU dissatisfaction from their decision. Existing variety of predictions of what scenarios were the most probable may now be analysed; in what aspect they were correct in predicitons. Consequences of the Brexit reality still cannot be clearly seen due to the Pandemic of Covid-19 with ongoing appearance and problems, but Post Brexit reality is, as well as, Pre Brexit reality used to be, a focus of the research object of many scholars and economists. The scientific study presents an overview of the resulting (possible) consequences of a "hard Brexit" scenario and compares them to contemporary results. The changes that were occuring before Brexit and are occuring after Brexit in the United Kingdom's economy and financial sector, complicated moreover by the Covid-19 pandemic situation, can be observed in economic indicators, financial and investment variables. This study concentrates on a historical evaluation of key variables that may have an impact on the economy and financial sector in order to demonstrate the evolution of the changes and relationships that exist due to the Brexit. Results of this research have led to contributing and clarifying certain essential facts having an impact on investment decisions of foreign investors throughout the world and for the EU member states.
\end{abstract}

Keywords: Brexit, Covid-19, economic, financial, globalization, uncertainty.

Cite this Article as: Darina SAXUNOVA, Corlise Liesl LE ROUX AND Manuel OSTER (2022)," Financial and Economic Impact of Brexit and COVID-19 in the United Kingdom", IBIMA Business Review, Vol. 2022 (2022), Article ID 834462, DOI: $10.5171 / 2022.834462$ 


\section{Introduction}

Brexit is an abbreviation for "British Exit" which means the last day of British longtime membership in the European Union. The United Kingdom left the European Community on January 31, 2020 and that was the commencement of the transition period that ended on December 31, 2020. No-Deal Brexit outcome had become more probable, i.e., no agreement on trade relations between EU negotiators and the UK Parliament, so that a so-called "hard Brexit" was the most likely scenario. As we know nowadays a Trade deal was signed in December 2020, but not sufficiently prepared, therefore Hard Brexit strategy to leave the European Union with a limited trade deal became reality. The United Kingdom, after leaving the international community of EU member states, is treated as a third country that has almost no trade arrangements with the EU. Consequently, the United Kingdom will no longer benefit from European fundamental freedoms. In particular, the essential free movement of capital for the country, to mention at least this aspect, and the associated financial pass rights, which allowed that UK-based financial institutions accessed to the European single market for financial products, ceased to be guaranteed. The following article gives an overview of the resulting (probable) consequences of a "hard Brexit" scenario and what, indeed, may be observed within 9 months of postBrexit period. The EU's chief negotiator stressed trade barriers, limits on citizens' movement and work visas changes are the most striking features since January $1^{\text {st }}$, 2021, alike cultural and educational vandalism can be observed after Brexit Day (Erasmus students exchange stopped, being replaced by Turing scheme financing of students' study abroad privileged certain group to obtain financial resources and it was not fair).

\section{Economic Power of the Financial Sector}

Globalization consists in the functioning of interactive relations and affairs among global institutions and enterprises. More than one-third of all banking business for major customers in the EU was conducted in the UK. (Theurer, 2016, p.1). The share of the country in the European banking business was thus higher than the shares of Germany, France and Italy together (Bundeszentrale für politische Bildung, 2016). In addition, a large part of the interest and currency derivatives denominated in euros was traded in London, where around 500 foreign banks were based (Berberi, 2014, p.5). Their daily trading volume was estimated by the Bank for International Settlements to be up to one trillion euros (Deutsches Institut für Wirtschaftsforschung, 2016, p. 687). The UK financial sector accounted for more than $10 \%$ of UK GDP, accounting for much of Britain's economic performance in 2016 but the vision of Brexit brought its consequences, because in 2019 the financial service sector contributed to the UK economy only by $6.9 \%$ of total economic output. (Moran, 2021) But still financial services industry employs over million people not even comparable to fishing industry (approximately 8000 people) and attention by the Government as if they paid more attention to fishing in the negotiation process that was criticised by the finance services industry, since the financial sector represents 7 percent of British GDP and more than 10 percent of its tax revenues. Such a centurial decision required a sensible leader and articulate negotiator for such a strategic step preparation supported with higher quality and thorough analysis of possible Brexit scenarios (Singh et al. 2020).

In particular, the city of London developed a prominent role within Europe as its largest financial centre (Jackson, 2016). The financial centre alone covered over 250 Banks enjoying free access to the single market because the United Kingdom was a member of the European community of states. It was making the financial centre the world's largest exporter of financial services according to the Economists (2014). London had also become the most important currency trading centre in euros and was considered the largest international insurance market. Half of the European investment banking activities were also supposed to be handled in London 
(Berberi, 2014, p.8). In addition, the European Banking Authority (EBA) was based in London with objectives of consistent and effective regulation of European banking institutions. The attractiveness of London as a financial centre was also a magnet for foreign direct investment as international investors considered London as a hub between the US, EU and Asia, as confirmed by the Institute of the World Economy. The City of London had therefore achieved an outstanding position as an international financial centre alongside New York and has continued to expand its leadership since the introduction of the euro compared to other European countries (Berberi, 2014, p.7). Worries to lose the financial centre position became reality as the EBA was already dislocated from London to be headquartered in Paris. The uncertainty, chaos and risk that was introduced into the market as a result of the Brexit caused volatility into many aspects of the economy and financial sector (Ghosh, et al. 2020). But accounting information systems should help to pacify and enhance the quality of management in an organization, and more importantly, the management performance (Khalid \& Kot, 2019), especially under such critical conditions.

The contribution of value generated by the financial services sector is shown in Figure 1. The value that has been added by the financial sector has been declining in both the UK and the EU since 2009, however in 2020 the UK financial services sector increased its value added in line with 2018 levels.

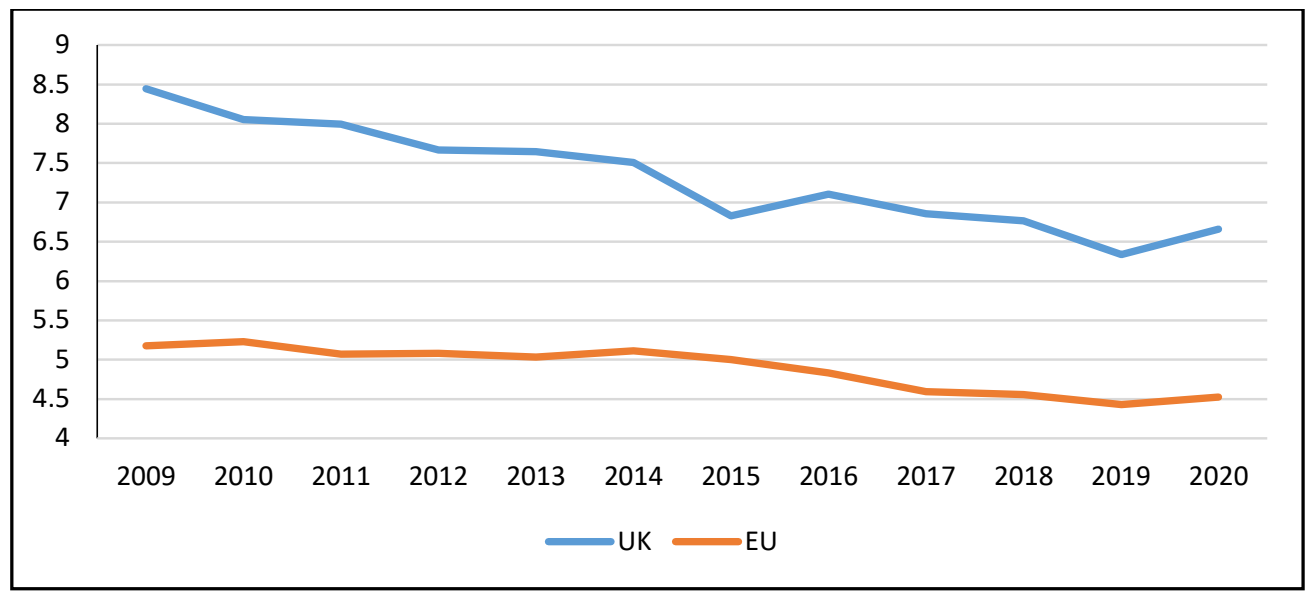

Fig. 1. Value Added by Activity: Financial Services

Source: Constructed by authors based on (OECD, 2021)

Free movement of capital and the European financial passport

The British financial sector was growing much faster than the OECD average since the accession of the United Kingdom to the European single market in the early 1990s, but coming Brexit brought clouds and not clear future. The main reason for the strong growth and attractiveness of the trading venue was in addition to liberal legislation on financial services mainly the possibility of using the European financial passport, which was at the center of the discussions about the consequences of Brexit (Deutsche Bundesbank, 2017). It formed part of the free movement of capital and determined the scope of the regulation and supervision of European financial services, such as loans, bank accounts and other financial services to customers (Fahrholz \& Hohlmeier, 2018).

It also favored financial institutions' access to the single European market, which was the largest trading area for UK-based banks with its 28 member states and more than 500 million consumers at those times. The 
rules of the financial pass stipulated that banks domicile in the EU had free access in all member states to offer financial products without operating a branch there (Huong Le \& Karlsson, 2016). Financial institutions established in a Member State, therefore, do not need additional authorization from another European State to offer financial services under the European legislation. Hwang and Kim (2018) in their research stress that financial institutions such as underwriters are motivated to maintain long-term business relationships with firms that appointed them as underwriters, and this relationship is considered more important to ensure a successful IPO process for IPO firms (Hwang \& Kim, 2018). In the case of a "hard Brexit", the European Union's fundamental freedoms also eliminated the financial passport rights and the unimpeded access to the single market as it was predicted by Fahrholz \& Hohlmeier (2018). Banks, insurance companies and other financial institutions would be forced to open a branch within the single market in order to maintain access to it (Huong Le \& Karlsson, 2016). Since the European financial passport also applied to institutions from non-EU countries, provided that they had a place of business in an EU country, they would be affected by the abolition of the regulations too.

Amsterdam overtook London as Europe's largest share trading center in January after Brexit saw about half of the city's volumes move to the continent. An average 9.2 billion euros ( $\$ 11$ billion) of shares a day were traded on various Dutch stock financial markets in January, a more than fourfold increase from December 2020, according to data from CBOE Europe. That compares to average daily volumes in London of 8.6 billion euros. Swiss shares trade returned to London which was not included to the table figures yet. The European Union has not permitted investors inside the EU to trade shares in companies such as Airbus SE and BNP Paribas SA from the United Kingdom. Other areas including euro swap trading also shifted from the U.K. capital to both the EU and New York's Wall Street.

Table 1: Shares trading shift out of the City of London

\begin{tabular}{|l|c|c|c|c|c|}
\hline $\begin{array}{c}\text { Average daily shares } \\
\text { trading in Euro }\end{array}$ & London & Amsterdam & Frankfurt & Milan & Paris \\
\hline December 2020 & $\begin{array}{c}14.6 \\
\text { billion }\end{array}$ & 2.2 billion & 4.6 billion & 2,2 billion & 3.9 billion \\
\hline January 2021 & 8.6 billion & 9.2 billion & 5.9 billion & 2.6 billion & 6.1 billion \\
\hline August 2021 & $\begin{array}{c}7.63 \\
\text { billion }\end{array}$ & 8.63 billion & 7.97 billion & $\begin{array}{c}2.47 \\
\text { billion }\end{array}$ & $\begin{array}{c}5.69 \\
\text { billion }\end{array}$ \\
\hline
\end{tabular}

Source: Constructed by the authors based on (Bloomburg.com) and (Vaghela, 2021).

In particular, for the many US and Asian financial services institutions that operate their European headquarters in London and transact their predominant EU business from there, the UK is no longer the gateway to the European single market. For the institutions of the financial sector, but also the companies of adjacent sectors, it was necessary to open a new location within the single market, which has a European banking license, to safeguard access to this large market. Following initial clarifications, the EU will not accept banking licenses to pure "mailbox companies" within the single market which continue to operate from
London. In particular, "for critical functions such as management, controlling and compliance, qualified personnel need to be present at the non-UK EU subsidiary at all time" emphasised by the experts from Deutsche Bundesbank. In order to meet these requirements, the large-scale relocation of jobs with further consequences resulting from them were assumed. Brexit already impacted on the relationship of financial groups within the financial market when several headquarters of London's financial centre's withdrawal occurred, and the future will show the investors' behaviour possible change. About 
$£ 1.5$ trillion in capital and assets amounting to about 14 percent of the total assets of British-based institutions and up to 10,000 jobs decline due to leaving from British industry outside UK as companies set up EU subsidiaries after Brexit. UK insurers lost their passporting rights and they cannot provide cross border services to any European Economic Area member states and vice versa. The UK-EU trade and Cooperation Agreement did not confirm equivalence for financial service providers. Cross -border contracts will be facilitated by obtaining this equivalence, which is necessity for setting a framework to enable bilateral agreements between the UK and the EU. (Simon, 2021) (Vaghela, 2021).

Shortly before the Brexit deadline (January 31,2020 ), Barclays, a British company, sent nearly $\$ 265$ billion of its assets to Ireland. JPMorgan Chase transferred $\$ 230$ billion to Germany, on February 21, the Financial Times reported that HSBC, Britain's largest bank by far, was relocating most of its revenue-producing divisions to Hong Kong as part of a larger pivot to Asian markets, where HSBC has traditionally been strong (Moran, 2021).

\section{Economic Impact}

Institute for World Economy stressed that with the loss of single market access and the elimination of the privilege of the financial passport, the influence of the UK financial sector and, in particular, London's influence as an international financial center threatened to slacken. The finance sector generated the United Kingdom's largest trade surplus of any economic sector, according to the Bank of England, with a positive balance of $\$ 50$ billion in 2019 . There was a risk that many of the European functionalities that were located in London would be relocated to other European financial centres or that international functionalities would be relocated back to New York (Oxenford, 2016).
Lavery and his research team (2019) examined the issue of Brexit as a creator of an opportunity for alternative European financial centres, since two of the main 'rivals' to the City of London, in the aftermath of Brexit, are Frankfurt and Paris. According to their opinion, the emerging competition between Frankfurt and Paris is shaped through four related axes: diversity, path dependency, territory and regulatory stability. (Lavery, McDaniel \& Schmidt, 2019). European disintegration by interrogating the interaction of fragmentary and integrative dynamics in the sphere of European finance has been focused on by many researchers recently. In addition to shifting capital, large-scale relocation involves relocating personnel and the entire infrastructure to alternative locations within the single market (Fahrholz \& Hohlmeier, 2018), (Saxunova, Le Roux, Oster, 2019).

\section{Labour Market}

Preliminary estimates suggested that 70,000 to 100,000 jobs may be affected by job relocation and job losses in the London financial center alone (Pricewaterhouse Coopers, 2016). Various major banks have already announced, immediately after the Brexit vote, to transfer parts of their workforce to European cities in the remaining EU states. HSBC plans to relocate 1,000 jobs to Paris, JPMorgan to relocate 4,000 jobs from London, and Morgan Stanley to deduct 1,000 jobs from the UK (Wohl, 2016).

The total workforce jobs that the financial services sector contributes is shown in Figure 2. The percentage of total workforce jobs for the financial sector as compared to all jobs in the UK is shown on the right axis. The financial sector contracted in the period before Brexit was announced, and since then the value remained stable. A slight increase was observed in 2020, however, the value returned back to the level seen from 2016 to 2019, in 2021. 


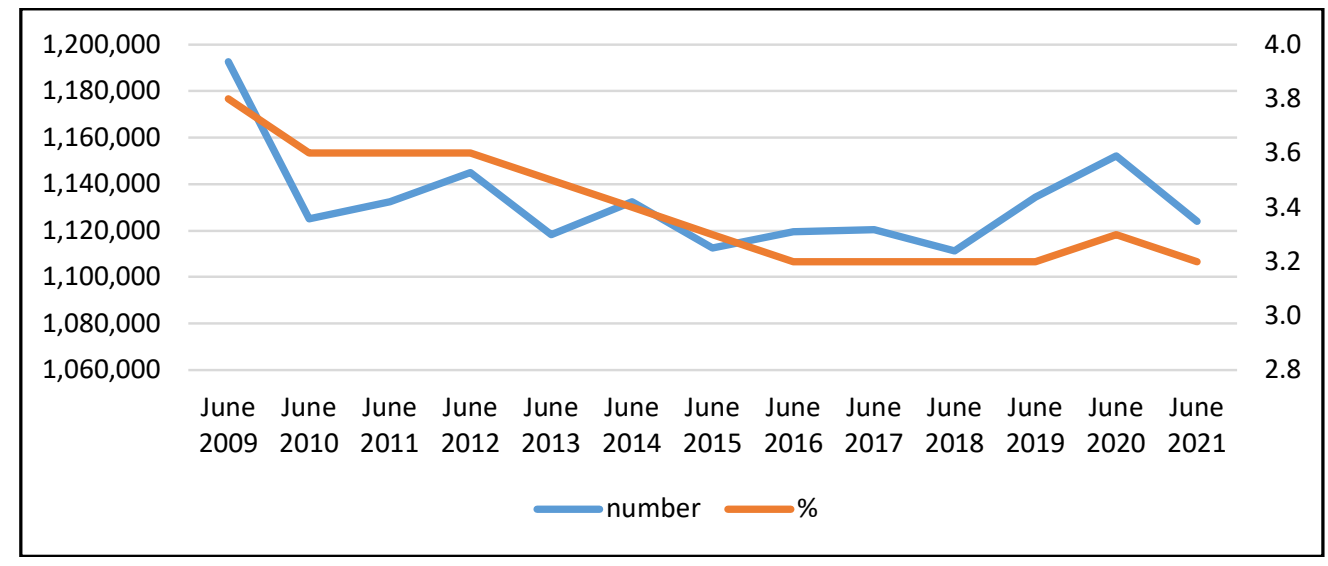

Fig. 2. Total workforce jobs: Financial Services

Source: Constructed by authors based on (OECD, 2021)

The impact of Brexit's uncertainty on the number of available jobs in the financial sector in London was already evident. While the number stagnated at a high level before the Brexit vote, the first slump in the months following the vote reached its lowest point in December 2016. The ensuing jump recovery was not long lasting. Since this high point in January 2017, which could be seen as a countermovement to the previous month, the numbers were declining. The closer the exit date was coming, the higher the uncertainty in the financial sector seemed to be; so, fewer jobs were created in the financial sector.
Insurance and reinsurance companies also benefited from the financial pass rights and can offer their products and services throughout Europe, subject to approval and control of their home country. Related to a relocation of banks or with the relocation of business fields, therefore, would be the insurance industry and other border industries, which work closely with the financial institutions. The fear of a "hard Brexit" and the associated cuts seemed to be growing bigger. A decline could be seen to be continued, as seen in Figure 3.

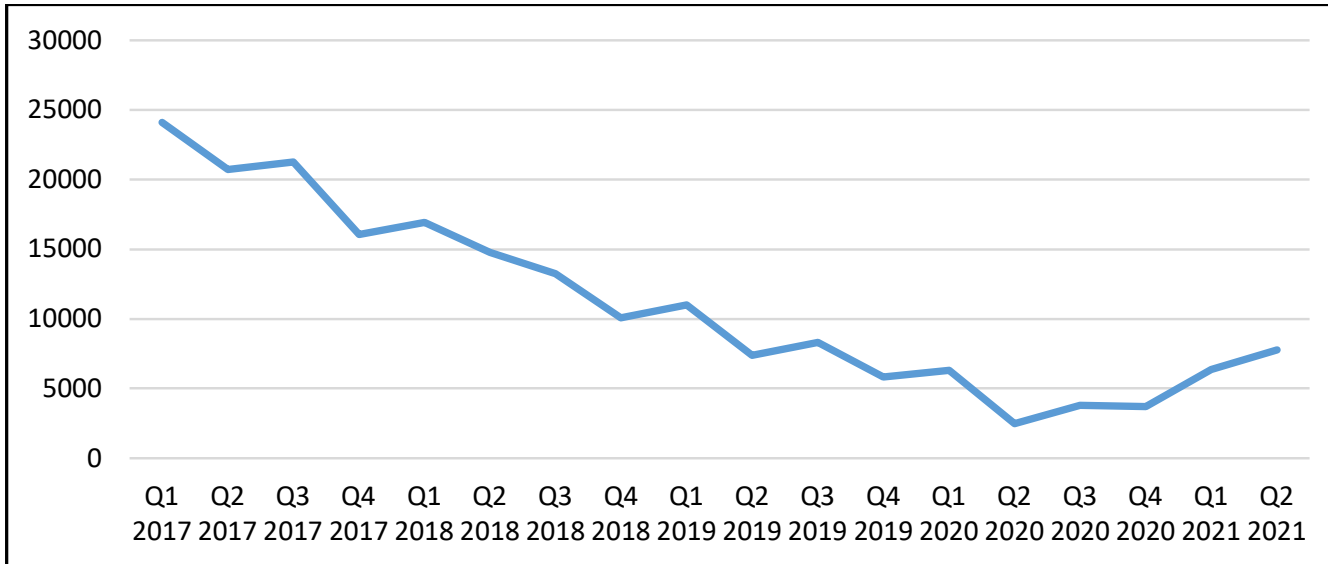

Fig. 3. Development of New Financial Service Jobs in the period of 2017- 2021 Source: Constructed by authors based on (Morgan McKinley, 2021), 
The relocation of jobs and the decline in the UK financial sector activities also affect European institutions such as the European Banking Authority (EBA). With the UK's exit from the single market, they no longer have a legal basis to control and regulate financial institutions. Consequently, the establishment must be relocated to the single market. Here, the corresponding deduction of jobs threatens with cuts in influence at the previous London location too. The Ministers of the remaining EU Member States had already voted on this issue in a meeting on 20 November 2017 and decided that the seat of the Authority would be relocated from London to Paris. More ominous still for the United Kingdom's financial sector, which represented nearly 7 percent of the country's GDP in 2019, is that it was starting to see real evidence of job loss. A modest 7,500 jobs left the United Kingdom for European Union cities by October 2020, Dublin became the most popular relocation city marked the most popular new location, according to the Ernst \& Young Financial Services Brexit Tracker. The comparison of the UK employment rate and the UK job vacancies (right axis) is shown in Figure 4.

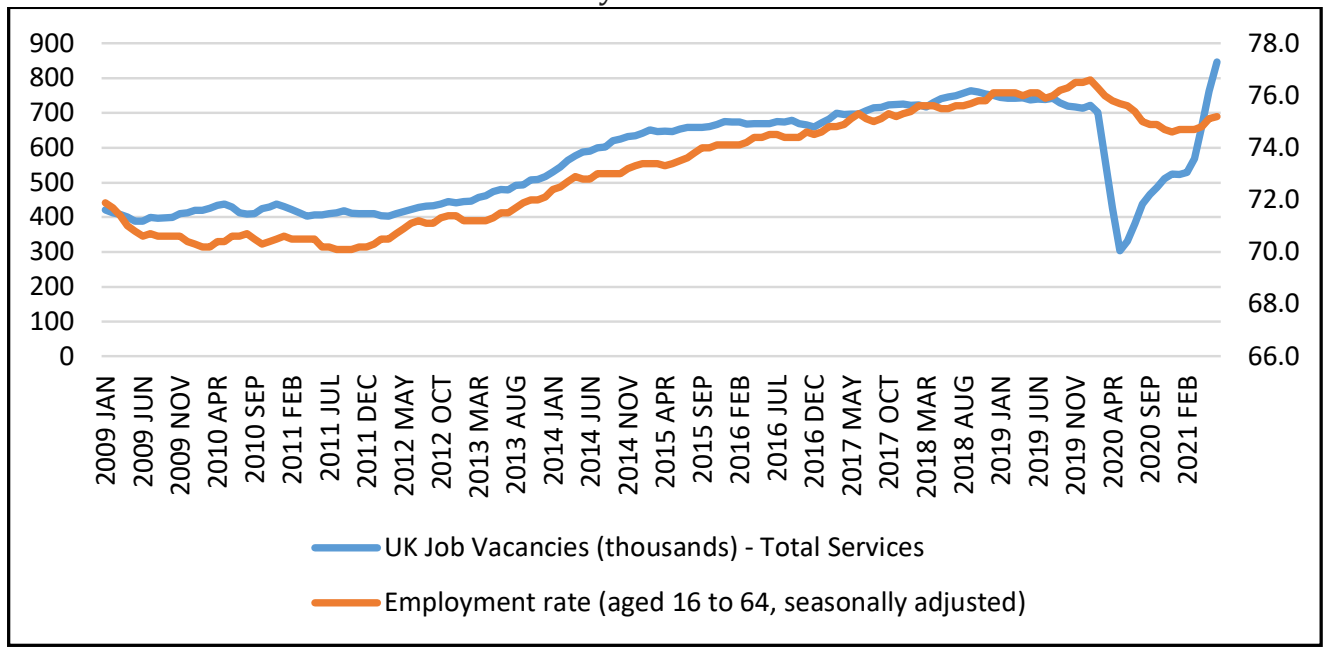

Fig. 4. Total UK job vacancies and unemployment rate

Source: Constructed by authors based on (OSN, 2021)

In 2021, the UK is facing job crisis, however not as initially expected. New job vacancies have been increasing to higher levels, at about 20 percent higher than their prepandemic levels. The crisis being faced is that even though the new vacancies are rising in the UK, the vacancies that are available do not match the requirements of the unemployed in what they are able and willing to do. The wage subsidies distributed to people that the UK provided as a result of the COVID-19 pandemic, as part of its furlough scheme (Coronavirus Job Retention Scheme) since March 2020, are planned to end in September 2021; after this period, many people may lose their working positions. The need for workers has been visible in nearly every occupation, including computer programmers, health care assistants and farmworkers.

More than 200,000 European Union citizens who were working in the UK moved out of the United Kingdom after Brexit so far. The future rights of the estimated 3 million nonBritish European Union citizens living in the UK and 1.8-3.6 million British citizens living in the EU fell directly within the scope of the Withdrawal Agreement, and are the subject of the citizens' rights negotiations. Before the EU Referendum in the UK, the intra-EU migration of Western Europeans was largely unremarked within their countries of residence (Favell and Nebe2009). The rights of citizens have faced a large degree of uncertainty and confusion, which will have lasting effects. 


\section{GDP and Foreign Investment}

The level of the financial services predetermines the attraction of the foreign investment as the investors prefer stable economic environment (Novackova et al., 2018). British business environment always represented an environment of stability and high quality of financial services. The UK financial sector, which accounts for less than $10 \%$ of the total UK value added (Fuest, 2016), would inevitably decline as a result of the developments above, resulting in declines in the UK economic growth and rising unemployment. Endangering the UK financial sector and related jobs poses significant risks to social security systems, which at least partially offset income losses. In addition, the reduction of jobs directly and indirectly entails the reduction of tax revenues. This concerns the abolition of the income tax in the same way as the excise duty on the associated decline in private consumption.

Globalization of the automotive industry implies the extension of the operations of a company beyond the borders of the country of origin, for the purpose of exporting products on new markets, with smaller costs and greater profits and Jaguar, Land Rover, would not be an exception; opening a new plant of Jaguar in Slovakia was believed to serve this purpose utilising the network of skilled labour force in SMEs - the automotive suppliers' network for JLR. (Bajzikova et.al, 2017; Saxunova et al, 2018). A specific source of Japan's competitive advantage in the automotive industry is the long-term cooperative relationship between automakers and suppliers (Asanuma, 1989; Cusumano \& Takeishi, 1991; Sako \& Helper, 1998). This competitive advantage may be distorted by the Brexit for Jaguar Land Rover (JLR).

The loss of single market for the UK is predicted to be especially enormous for car industry. For instance, JLR production stresses that more than $40 \%$ of its parts are imported from Europe. The manufacturing process goes through plants in Germany, Italy, Scotland, Poland, UK JLR plant, Czech Republic, UK again, to be finalised in
Slovakia. JLR manufactures more than 600,000 cars a year, its production is dependent on the efficient and effective transport management from suppliers to the manufacturing plants. It often has 10 trucks a day on the routes in order to support production. "Car industry utilises the free and frictionless trade offered by Europe's single market more intensively than almost any other sector: every car that rolls off the production line in a UK plant is made up of tens of thousands of parts that between them will have made hundreds of thousands of movements across the continent." (Henley, 2018)

Industry experts calculated that falling back on World Trade Organization tariffs, if Britain leaves the EU without a free trade agreement, would add $10 \%$ to the cost of assembling a car in the UK. The development of the coming months will show how precise the experts were. The car industry operates with low margin; therefore, the reduction costs is essential, and if there is an unexpected increase in manufacturing costs, this may be the reason for producers to consider setting up business elsewhere to stay competitive.

Increased tariff barriers will become the significant impact of a bad Brexit, apart from them non-tariff barriers will make production across borders more expensive due to the factors as: rules-of-origin checks; customs controls; compliance with different product standards and regulations between countries. The car industry pointed out that Britain needs to remain in the customs' union with a deal that "maintains the benefits of the single market".

The total possible cost of post-Brexit tariffs for the UK car industry is estimated by industry analyst about $€ 3$ bn a year - of which JLR would bear approximately one third, since it exports one in three cars from the UK. (Henley, 2018).

\section{Data And Methodology}

The changes that occurred in the UK economy and financial sector can be observed in economic indicators, financial and investment variables. This paper will 
show a historical evaluation of key variables in order to demonstrate the evolution of the changes and relationships that exist. The historical data of 34 variables will be analysed to determine the changes and relationships. The majority of the analysis will be focused on the 2016 and 2021 period in order to observe the longer-term effects of Brexit, followed by the impact of COVID-
19. The data were obtained from Refinitiv DataStream and the European Commission (Eurostat, 2021). The variables included in the study are detailed in Table 2 . All these data were used for analysis of the individual indicators of the Economic Sentiment Indicator (ESI) and illustrated in the following figures numbered from 5 to 13 .

Table 2: Economic and financial variables included in the study

\begin{tabular}{|c|c|}
\hline Variable & Code \\
\hline UK GDP AT MARKET PRICES (CVM) CONA & UKGDP \\
\hline UK BALANCE OF PAYMENTS: CURRENT ACCOUNT BALANCE CURA & UKCURBALB \\
\hline $\begin{array}{l}\text { UK BALANCE OF PAYMENTS: FINANCIAL \& CAPITAL ACCOUNT BALANCE } \\
\text { CURN }\end{array}$ & UKCAFBALA \\
\hline UK VISIBLE TRADE BALANCE - BALANCE OF PAYMENTS BASIS CURA & UKVISBOPB \\
\hline $\begin{array}{l}\text { UK MONEY SUPPLY M0: NOTES \& COINS IN CIRC.OUTSIDE BANK OF } \\
\text { ENGLAN }\end{array}$ & UKM0 \\
\hline $\begin{array}{l}\text { UK MONEY SUPPLY M1 (ESTIMATE OF EMU AGGREGATE FOR THE UK) } \\
\text { CURA }\end{array}$ & UKM1 \\
\hline UK MONEY SUPPLY M2: RETAIL DEPOSITS AND CASH IN M4 (EP) CURA & UKM2 \\
\hline $\begin{array}{l}\text { UK UK MONEY SUPPLY M3(ESTIMATE OF EMU AGGREGATE FOR THE UK) } \\
\text { CURA }\end{array}$ & UKM3 \\
\hline UK MONEY SUPPLY M4 (EP) (METHOD BREAK JAN 2010) CURA & UKM4 \\
\hline UK FT ALL SHARE INDEX (EP) NADJ & UKSHRPRCF \\
\hline UK GBP STERLING EFFECTIVE EXCHANGE RATE INDEX NADJ & UKXTW \\
\hline UK CONSUMER CONFIDENCE INDICATOR - UK SADJ & UKCNFCONQ \\
\hline UK UNEMPLOYMENT CLAIMANT COUNT VOLA & UKUNPTOTO \\
\hline UK LFS: UNEMPLOYMENT RATE, ALL, AGED 16 \& OVER SADJ & UKUN\%016Q \\
\hline UK LFS: UNEMPLOYED: AGED 16+ VOLA & UKMGSC \\
\hline $\begin{array}{l}\text { UK M4 LENDING: PRIVATE NON-FINANCIAL CORPORATIONS - LOANS } \\
\text { CURA }\end{array}$ & UKBANKLPB \\
\hline UK CBI ENQUIRY: BUSINESS OPTIMISM NADJ & UKCNFBUSR \\
\hline UK COMPANY INSOLVENCIES VOLA & UKBNKRPTO \\
\hline UK CPI INDEX 00: ALL ITEMS- ESTIMATED PRE-1997 NADJ & UKCONPRCF \\
\hline FTSE 100 - PRICE INDEX & FTSE100 \\
\hline FTSE ALL SHARE - PRICE INDEX & FTALLSH \\
\hline FTSE 350 BANKS $€$ - PRICE INDEX & FT33B3E \\
\hline FTSE 350 FIN SVS $£$ - PRICE INDEX & FT33GFE \\
\hline FTSE 350 FD PRODUCERS $€$ - PRICE INDEX & FT33FCE \\
\hline FTSE 350 GEN RETAILERS $€$ - PRICE INDEX & FT33GRE \\
\hline FTSE 350 GENERAL INDS $£$ - PRICE INDEX & FT33GIE \\
\hline FTSE $350 \mathrm{R} / \mathrm{E}$ IVST SVS $£$ - PRICE INDEX & FT33RME \\
\hline TR UK GVT BMK BID YLD 10Y ( $(€)$ - RED. YIELD & TRUK10T \\
\hline TR UK GVT BMK BID YLD 3M ( $€$ ) - RED. YIELD & TRUK3MT \\
\hline EURO TO UK $£$ (ECU HISTORY WMR) - EXCHANGE RATE & ECURRSP \\
\hline JAPANESE YEN TO UK $£$ (WMR) - EXCHANGE RATE & JAPAYEN \\
\hline US \$ TO UK $£$ (WMR) - EXCHANGE RATE & USDOLLR \\
\hline $\begin{array}{l}\text { UK BPM6:BOP:FA:A/L:FDI:BAL.:TOTAL INV(S1- } \\
\text { TOTAL)NET:NET_TOTINV:NE }\end{array}$ & UKMU7M \\
\hline UK BPM6:BOP:IIP:BALANCE:FDI:A/L:IIP(S1-TOTAL)(NET:NET_IIP:NET) & UKMU70 \\
\hline
\end{tabular}

Source: Refinitiv

Darina SAXUNOVA, Corlise Liesl LE ROUX AND Manuel OSTER, IBIMA Business Review, 
Variables will be grouped together in order to determine effects in different parts of the economy and financial sector. The initial analysis will be based on the sentiment in market based on the Economic Sentiment Indicator (ESI) as well as two confidence indicators and an insolvency indicator. GDP and CPI will be evaluated along with the confidence indicators, followed by the unemployment and claims values, balance of payment data and money supply. The final parts of the analysis explore the foreign direct investment, interest rates, exchange rates and indices to demonstrate the various effects caused by Brexit and Covid19.

\section{Findings and Analysis}

The Economic Sentiment Indicator (ESI) is a composite indicator provided by the European Commission and is composed of five sector specific confidence indicators with different weights:
- IND: Industrial confidence indicator $(40 \%)$

- $\quad$ SER: Services confidence indicator (30\%)

- CSM: Consumer confidence indicator (20\%)

- RET: Retail trade confidence indicator (5\%)

- CST: Construction confidence indicator (5\%)

- ESI: The Economic sentiment indicator is a composite measure $($ average $=100)$

The ESI is a weighted average of the balances of replies to selected questions addressed to firms in five above-mentioned sectors covered by the EU Business and Consumer Surveys and to consumers. The composite indicators from the ESI for the UK for the period from 2009 to 2021 are shown in Figure 5, with the ESI on the right axis, and the five sector specific confidence indicators on the left axis.

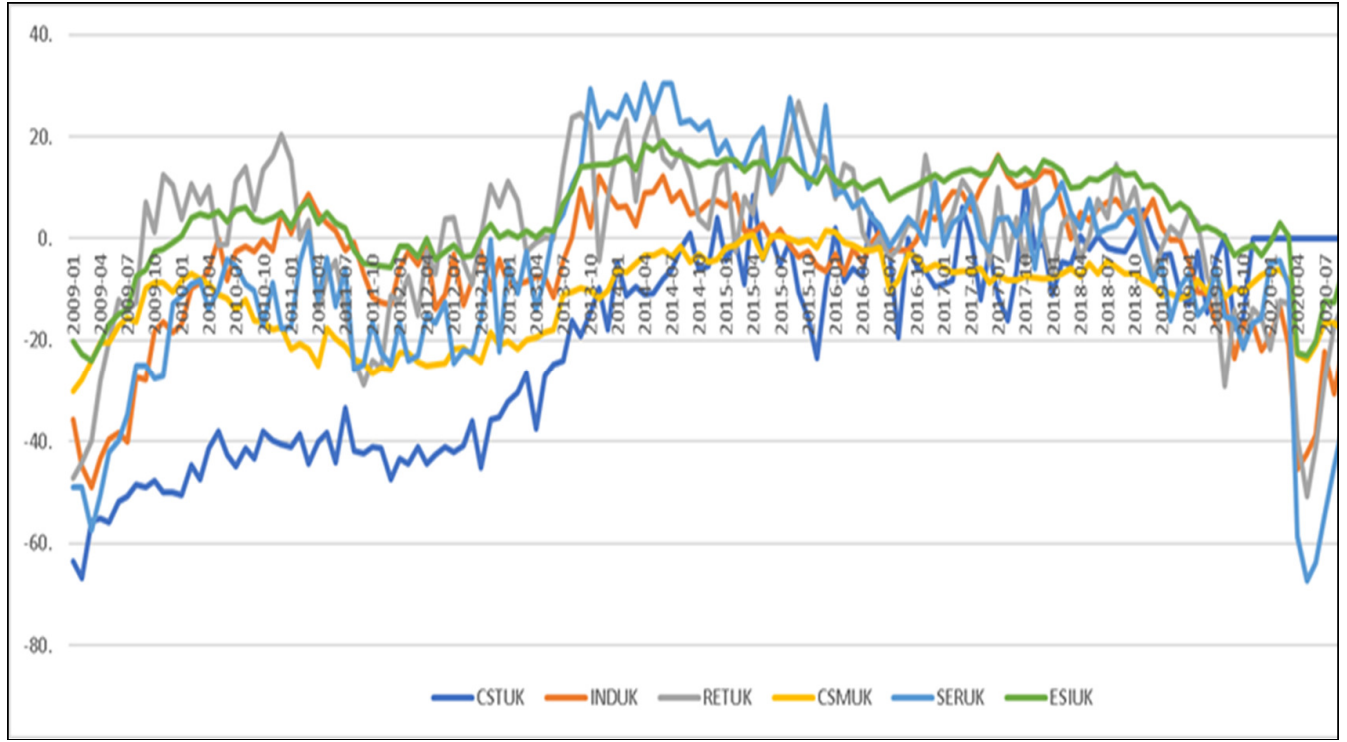

Fig. 5. Economic Sentiment Indicators for the UK

Source: Constructed by authors based on (Refinitiv, 2021)

Figure 6 shows an overall downward trend since the referendum held in June 2016. COVID-19 had a drastic effect of the indicators in April 2020 shown by the volatile drop in all the indicators, except for Construction confidence indicator which reduced to zero in November 2019, followed by the remaining indicators in 
January 2021 due to the official exit of the UK from the EU.

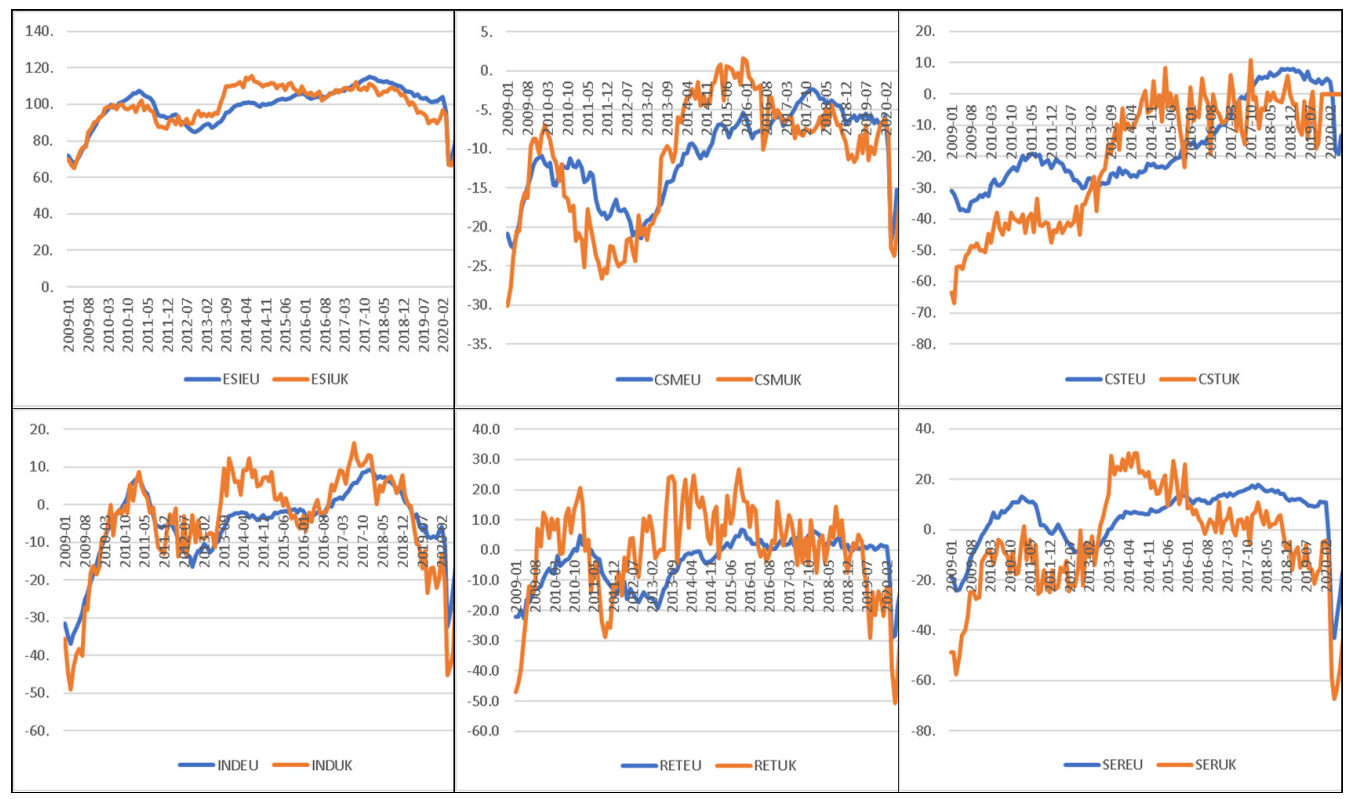

Fig. 6. Economic Sentiment Indicators for the UK

Source: Constructed by authors based on (Refinitiv, 2021)

Figure 6 shows the composite indicators for the UK and the EU from 2009 to 2021 for the ESI and the five sector specific confidence indicators. The ESI in the UK was decreasing since 2013, with brief periods of increases from that date, before COVID-19 was declared a global pandemic. The ESI in the EU, unlike the ESI in the UK was on a continuous upward trend from 2012 to 2017, however during 2017, both the EU and UK trend was decreasing showing a lack of confidence across all the sectors. The prolonged period since the referendum in 2016 until the actual exit of the UK from the EU did not aid the confidence levels in any manner. The uncertainty or fear that is present adds volatility into the market (Ghosh, et al. 2017). The unstable confidence indicators were further damaged in 2020. Reporting ended for the UK early in 2021, however the EU demonstrated a rebound of confidence during 2020, followed by a substantial increase in confidence in 2021, after the UK exited the EU, with consumer and services confidence indicator showing the largest percentage change in 2021.

Figure 7 shows consumer confidence (UKCNFCONQ), business optimism (UKCNFBUSR) as well as the company insolvency volume (UKBNKRPTO) from 2009 to 2021. Company insolvency volume is linked to the right axis. The consumer confidence is stagnant with a slight downward trend from 2015. The business optimism showed a sharp increase at the end of 2016, however since 2017, the trend has been volatile, with a sharp decrease in 2018, followed by a larger decrease in 2020 as a result of COVID-19. In 2016 to 2018, the company insolvencies showed an increase in a number of quarters. Company insolvencies were decreasing in 2019, however COVID-19 caused the volume to increase. Business Optimism in the UK reached a twelve year high in Q2 of 2021, as a combination of COVID-19 restrictions decreasing as well as the official exit of the UK from the EU. 


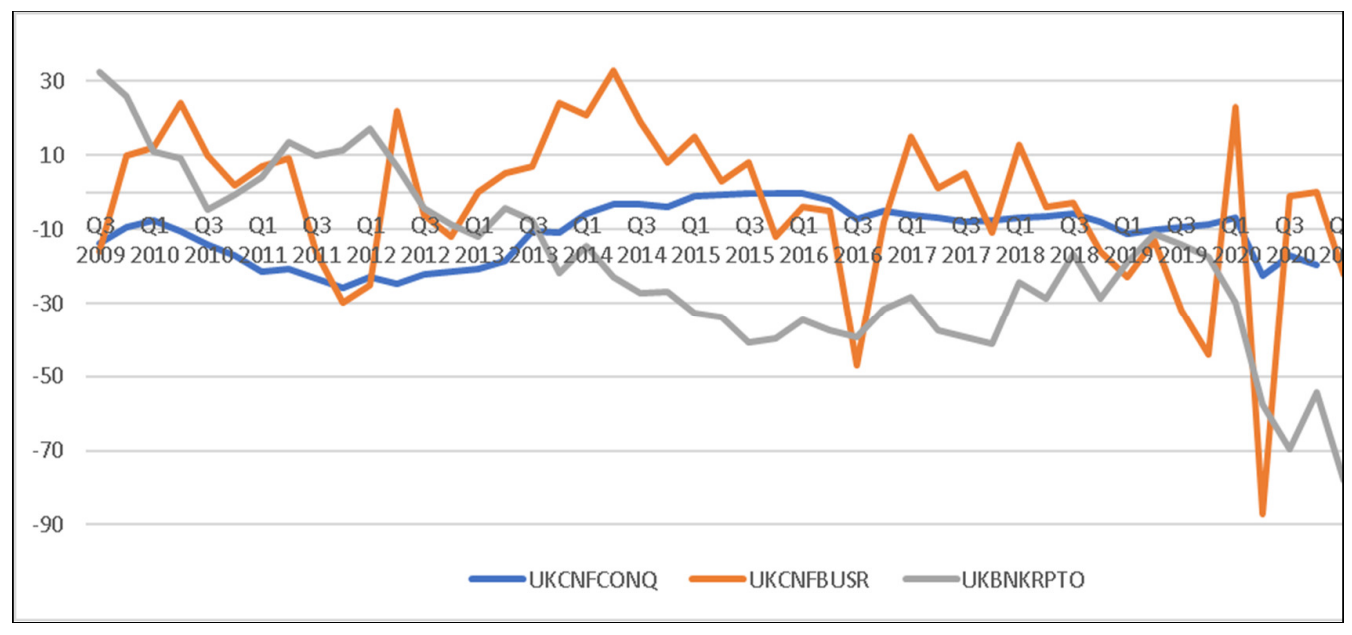

Fig. 7: Consumer confidence, business optimism and company insolvency volume in the UK

Source: Constructed by authors based on (Refinitiv, 2021)

UK GDP (UKGDP) and UK CPI (UKCONPRCF) comparison is illustrated in Figure 8, with the percentage change in both the GDP and CPI on the right. The GDP and CPI indicators show a continuously increasing trend from 2009 to 2020, but an evaluation of the percentage changes show small erratic variations in the consumer price index. COVID-19 caused the UK GDP to drop substantially as the whole world came to a standstill in April 2020, however, GDP rebounded sharply in the next quarter, followed by a second drop and rebound, albeit not as drastic. The uncertainty that COVID-19 brought with it into the market has been clearly observed in the variables discussed so far.

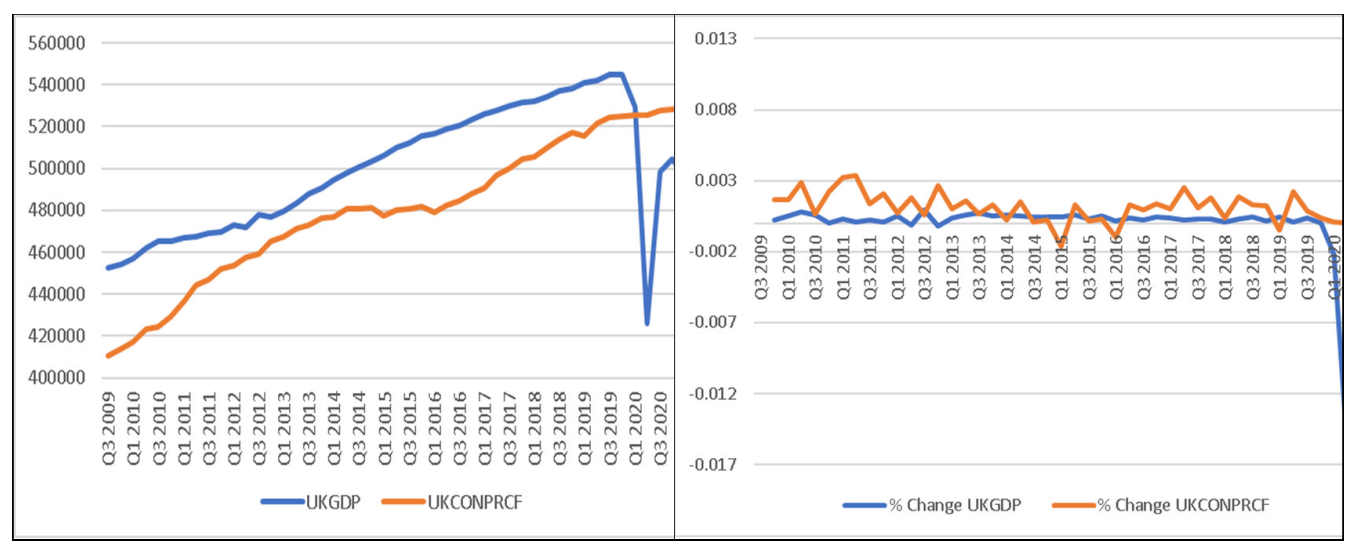

Fig. 8. Confidence indicator, GDP, and CPI in the UK

Source: Constructed by authors based on (Refinitiv, 2021)

The unemployment values (UKMGSC), unemployment claims (UKUNPTOTO) and unemployment rate (UKUN\%016Q) for the UK are shown in Figure 9. The employment rate is linked to the right axis. The unemployment rate and unemployment values were decreasing while the unemployment claims were increasing since the announcement of Brexit in 2016. COVID-19 caused all three variables to increase in 2020, however a reversal of trend is observed in 2021, indicating an 
improvement which is in line with the confidence indicators.

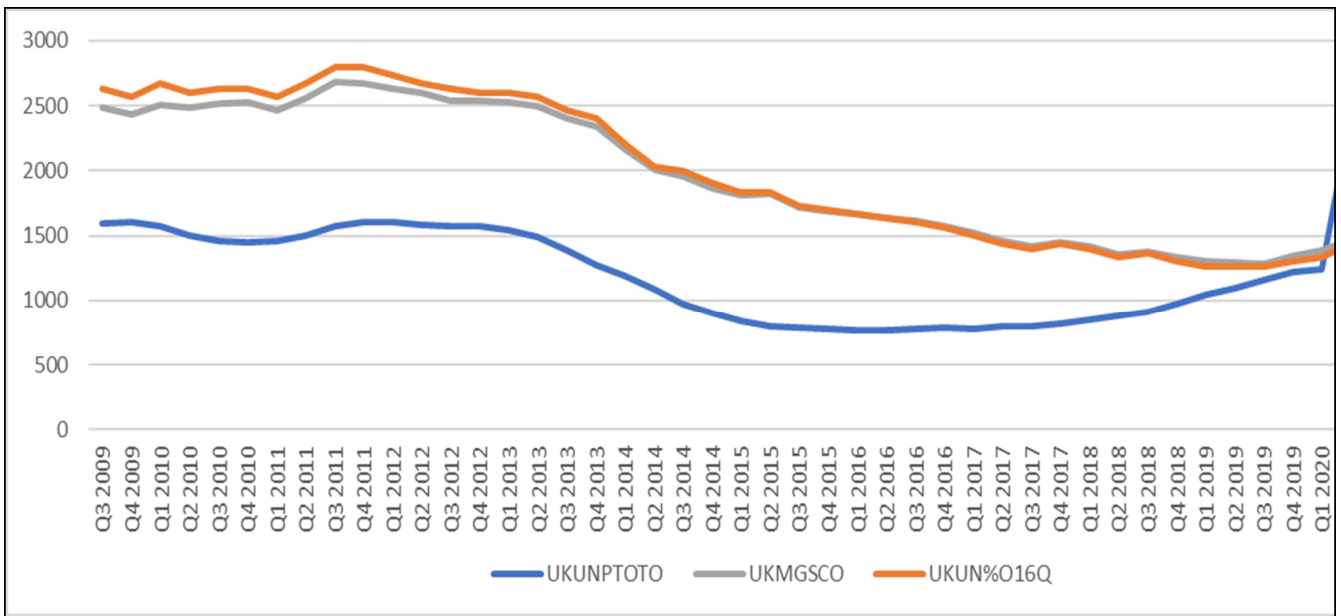

Fig. 9. Unemployment

Source: Constructed by authors based on (Refinitiv, 2021)

The balance of payments for the current account (UKCURBALB), financial and capital account (UKCAFBALA) as well as the visible trade balance (UKVISBOPB) is shown in Figure 10 on the left. On the right, the money supply based on different indicators, M0, M1, M2, M3, M4 and M4 lending (UKBANKLPB), are shown. The financial and capital account balance has shown a volatile movement with a low point reached that was last seen in 2011 followed by a lower level at the onset of COVID-19. The current account as well as the visible trade balance have both been decreasing in 2018, with the balances reaching new levels in 2020 that had not been during the prior ten years. M0 and M4 lending have been stagnant, however, the other money supply indicators have been increasing over the past few years.

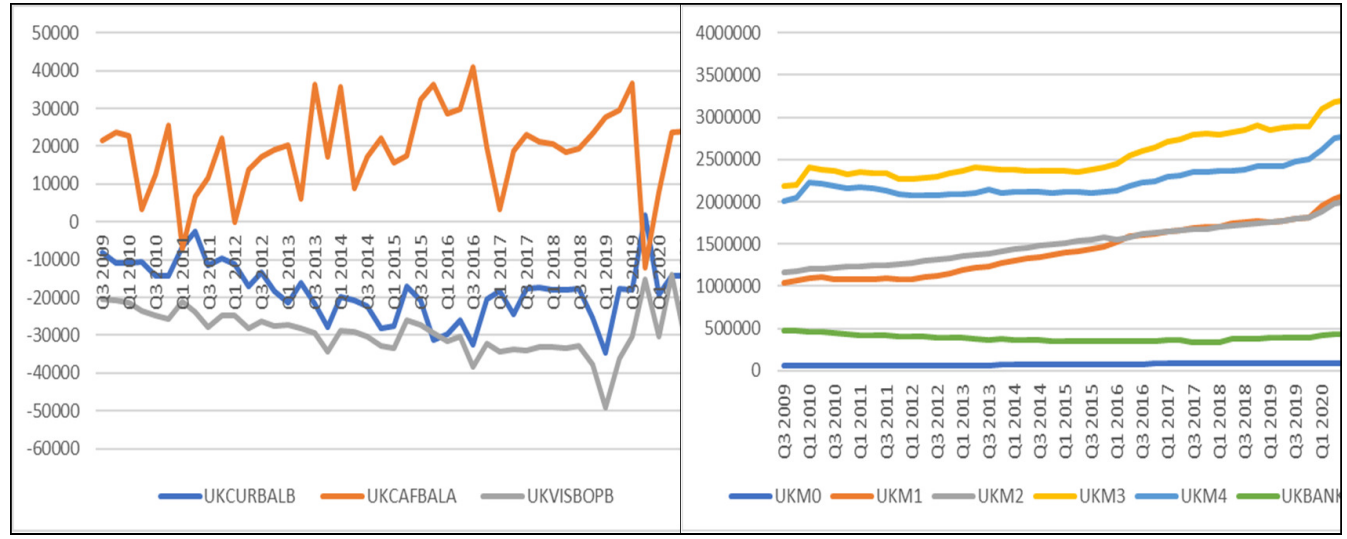

Fig. 10. Balance of payments and Money supply in the UK Source: Constructed by authors based on (Refinitiv, 2021) 
The foreign direct investment (left), interest rates (middle) and exchange rates (right) are shown in Figure 11. The total FDI (UKMU7M) decreased drastically in 2016, followed by a small upturn in 2017, however, the International Investment Position (UKMU70) has turned negative during 2017. The 3-month yield (TRUK3MT) has been increasing consistently in 2017 and 2018. The 10-year yield (TRUK10T) has a mixed reaction, with an erratic pattern since 2016 , followed by a downturn in 2018. The exchange rates of the EUR, USD and JPY (right axis) against the GBP saw volatile movements since 2015. The GBP showed a sharp weakening in 2016, followed by a slight recovery, however, a rebound was only observed in 2021.

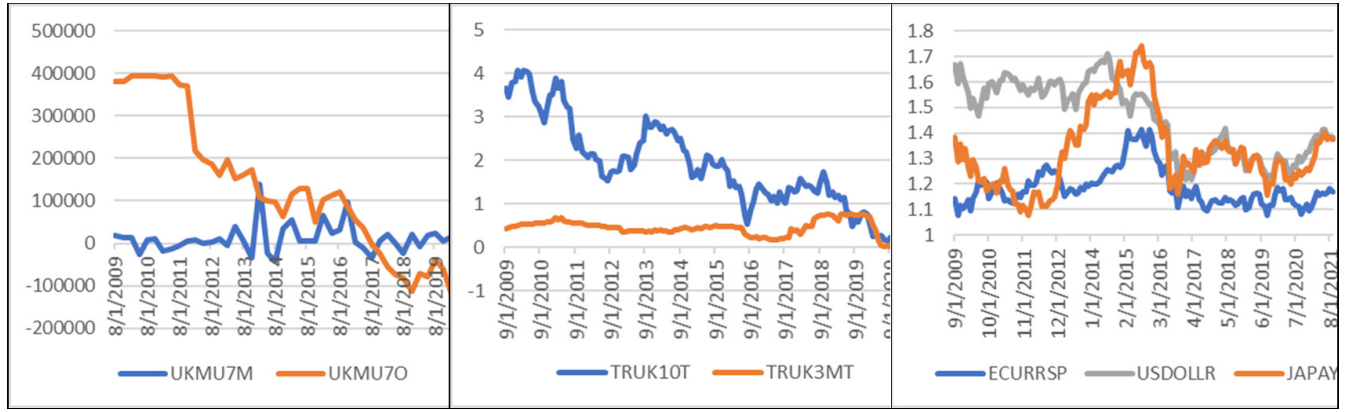

Fig. 11. FDI, interest rates, and exchange rates

Source: Constructed by authors based on (Refinitiv, 2021)

The FTSE indices since 2009 are shown in Figure 12 . The indices are mostly stagnant; however, the FTSE 350

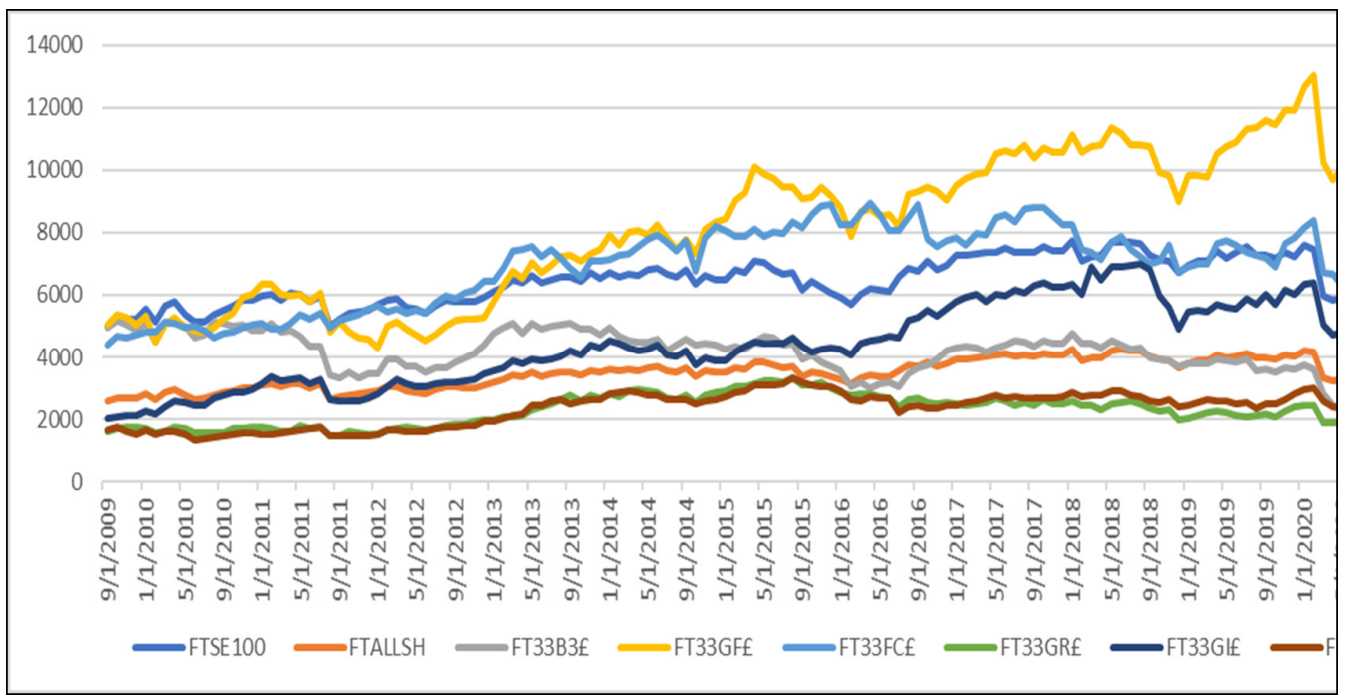

Fig. 12. FTSE Indices

Source: Constructed by authors based on (Refinitiv, 2021)

Financial Services Index has shown tremendous growth since 2016. Overall, in the remaining indices, COVID-19 impacted them significantly, and the prices have 
rebounded in 2021, reaching price levels that were last observed at the beginning of 2020. Figure 13 compares the FT All Share Index (UKSHRPRCF) with the GBP Sterling
Effective Exchange Rate Index (UKXTW, right axis). The Sterling Index saw a sharp decrease in 2016 and similar

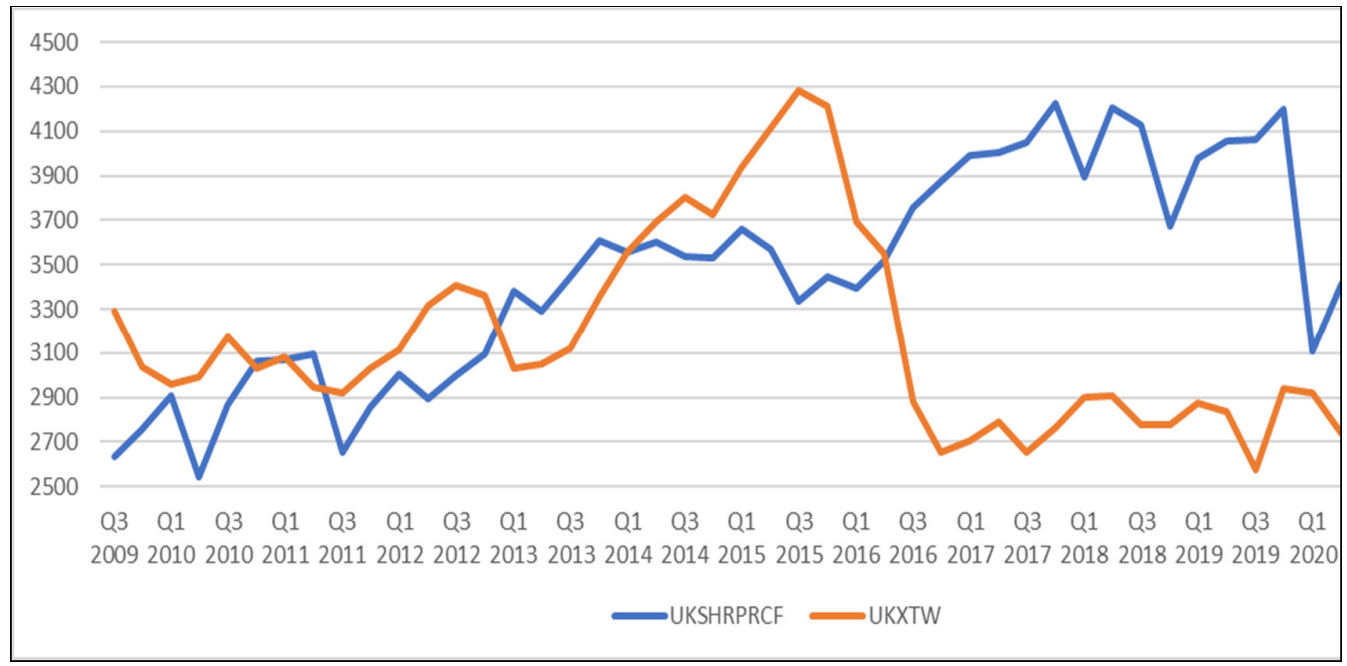

Fig. 13. FT All Share Index and Sterling Effective Exchange Rate Index

Source: Constructed by authors based on (Refinitiv, 2021)

to the exchange rates seen in Figure 12, the currency is still hovering in a tight range from 2016, however, the price broke out at the beginning of 2021. The FTSE All Share Index showed some improvement in 2016 and 2017, however in 2018, the index performed poorly, but rebounded in 2019. COVID-19 set the index back to 2012 levels, however during quarter 3 of 2020, in line with increased confidence indicators, the FTSE All Share Index quickly increased back to price levels of 2019. The EU financial markets experienced similar volatility as a result of COVID-19, with increased comovement in times of uncertainty (Le Roux, et al. 2020).

\section{Conclusion and Outlook}

The impact of Brexit on the UK economy and on the financial sector depended mainly on the agreement the United Kingdom Government makes with the European Union on how to shape future economic relations.

Overall, Brexit became economically expensive for the UK. After analyzing the impact on the UK financial and economic sector, the developments in the UK were negatively affected by Brexit which was further impacted by Covid-19. However, the large share of the financial sector in British gross domestic product indicates that its decline seriously endangers the country's prosperity. The strong uncertainty in the industry was already causing a large-scale job relocation, the decline in the influence of the city of London as an international financial center and its associated effects.

The lockdown phenomenon, the consumer behavioural changes, as well as reduced demand and disruption of the supply chain have contributed to the challenges that industrial production is facing, generating losses that will not be easily recovered (Tudorache et al., 2021,p.2), Moreover, Great Britain must cope with the Brexit problems. Covid-19 initially had a drastic negative effect across all the variables considered, however, as the pandemic progressed, fear was replaced by optimism which increased confidence and performance within the last year. If optimism levels can be sustained, the UK outlook is positive. The management of the unprecedented circumstances in the UK, 
especially with the combination of Brexit and Covid-19, will require time and continuous monitoring and prompt adjustments to ensure that the UK remains as a strong global economy. Historically, London always retained competitive advantages in financial services thanks to its legal system, business environment, and highly skilled labor. The city definitely made steps to incentivize financial companies to stay in London, but many companies are waiting, waiting was also forced by COVID19 circumstances, and after first results and consequences, will make decisions about new investments or hiring new employees in the UK, but will try to orientate to Asian and other markets, as declared in many articles, since the EU transferred its institution to the EU member states.

Other British businesses need to deal with customs controls, tariffs on goods, additional food safety forms, and myriad other paperwork to trade with the European Union; more than 150,000 British enterprises have never traded with the countries beyond the European member states. They have no experience at dealing with customs and will have to learn a new customs system which may cause losses in British industries that were depending too much on the trade with the businesses in the European Union. Rules-of-origin requirements for the EU international trade are in effect and British traders must get familiar with the documentation to be able to determine whether a product leaving Britain is to qualify for tariff-free trade with the European Union or face customs tariffs. The 300 pages document on the regulations is in effect: Borders with European Union was prepared only in July 2021, 7 months after Trade agreement of the Brexit Deal was approved with almost 50 pages material serving as manual for merchant with the EU. There was no time to organise courses for teaching and training labour force. For many businesses, Brexit has become a logistical, regulatory and administrative burden for which there was indeed no time to be prepared. The real cost of business trade for the United Kingdom caused by additional paperwork for customs declarations and other expenses of trade will be computed in years to come.
The first immediate tangible benefits of Brexit for businesses were the end of political debates, very often not constructive and betraying the uncertainty of discussants, the best explained by Shakespeare question about Brexit: to be/happen or not to be/happen. As if there was any chance to change the result of referendum for EU supporters. Development of the country after Brexit may be counted as a benefit as well. In many cases for supporters of Brexit, it was always about sovereignty, not business, and they hope it will allow Britain to revise its immigration laws.

Just an interesting step of The British Treasury was cancelling 'so called a sexist tax, VAT (a type of sales tax) immediately on January 1,2021 when Brexit went to effect, but if there are any substantial short-term gains from Britain's new trading arrangement with the European Union, they may not be visible because disruption brought by Brexit will be hidden also by the pandemic. The British economy experienced its deepest recession in more than 300 years. The governor of the Bank of England estimated and communicated to the Parliamentary committee that the Brexit deal would cost the British economy about 2 percent of gross domestic product over the next few years. (Nelson, 2021)

The investment and trade markets of the UK and their revival into pre-Brexit times, both locally and internationally, are an area for further research in order to determine the long-term impact of Brexit and its position in terms of globalization.

\section{Notes}

- The leather chemicals and dyes used in making the seat trim sets for Jaguars and Land Rovers are sourced in Germany and Italy and imported to Scotland, where they are used to tan UK rawhides. The hides are then shipped to Poland, where they are cut and sewn into seat sets before being delivered - at the exact moment they are needed - to a UK JLR plant. Similarly, a seat frame starts with German steel 
being pressed into sub parts in the Czech Republic. Those parts are then painted and welded into a seat frame in the UK, assembled, and finally re-exported for fitting into a vehicle at the company's new facility in Nitra, Slovakia (Henley, 2018).

- Increased tariff barriers: A tariff is imposed by a country or an economic bloc on an import from overseas, and is calculated as a percentage of the value of the imported good.

- $\quad$ Sexist Tax: Tax collected on tampons and other sanitory products

\section{References}

- Asanuma, B. (1989),'Manufacturer-supplier relationships in Japan and the concept of relation-specific skill,' Journal of the Japanese and International Economies, 3(1), 130.

- Bajzikova, L.,Novackova, D., and Saxunova, D., (2017), 'Globalization in the case of automobile industry in Slovakia', Proceedings of the 30th International-BusinessInformation-ManagementAssociation (IBIMA), ISBN: 978-09860419-9-0, 8-9 November 2019, Madrid, p. 4879-4893

- $\quad$ Benson, M. and Lewis, Ch., (2019), 'Brexit, British People of Colour in the EU-27 and everyday racism in Britain and Europe', Ethnic and Racial Studies, 42 (13), 2211-2228, DOI: 10.1080/01419870.2019.1599134

- Berbéri, C., (2014), 'The City of London and the Euro'. in: Wissenschaftliche Schriften des Fachbereichs Wirtschaftswissenschaften, Hochschule Koblenz - University of Applied Sciences, Nr. 14 - 2014 Mai.

- Bundeszentrale für politische Bildung (2016), Mögliche wirtschaftliche Folgen des Brexit. [Online], [Retrieved December 22, 2020],

http://www.bpb.de/international es/europa/brexit/228809/wirtsch aftliche-folgen

- Cusumano, M. A., and Takeishi, A., (1991),'Supplier relations and management: A survey of Japanese, Japanese-transplant, and U.S. auto plants,' Strategic Management Journal, 12(8), 563-588.

- Deutsches Institut für Wirtschaftsforschung (2016), 'Brexit: Was steht für den britischen Finanzsektor auf dem Spiel?' [Online], [Retrieved June 20, 2021],

https://www.diw.de/documents/ publikationen/73/

diw 01.c.540659.de/16-31-3.pdf

- Eurostat, (2021), Economic sentiment indicator. [Online], [Retrieved September 10, 2021], https://ec.europa.eu/eurostat/dat abrowser/view/teibs010/default/ table?lang=en

- Fahrholz, C. and Hohlmeier, M. (2018), 'The impact of Brexit on financial markets - taking stock.' [Online], [Retrieved September 10, 2019],

https://www.mdpi.com/22277072/6/3/65/htm

- Favell, Adrian, and Tina Nebe (2009). "Internal and External Movers: East-west Migration and the Impact of EU Enlargement", (eds) Adrian Favell, Ettiore Recchi, 205-223. London: Edward Elgar.

- Fuest, C., (2016), 'Denkfabrik: Diese Kettenreaktion droht nach dem Brexit.' [Online], [Retrieved September 10, 2019], http://www.wiwo.de/politik/euro pa/denkfabrik-diesekettenreaktion-droht-nach-dembrexit/13638662.html

- Ghosh, B., Le Roux, C., and Ianole, R., (2017), 'Fear estimation-evidence from BRICS and UK'. International Journal of Applied Business and Economic Research,15(4), 195207.

- Ghosh, B., Le Roux, C., and Verma, 
A., (2020), 'Investigation of the fractal footprint in selected EURIBOR panel banks', Banks and Bank Systems, 15(1), 185.

- Huong Le, T. and Karlsson, M., (20.17), 'UK post-Brexit; The Service Economy Fallacy'. [Online], [Retrieved September 10, 2019], https://www.diva-

portal.org/smash/get/diva2:1075 580/FULLTEXT01.pdf

- Hwang, K. J., and Kim, N. Y., (2018), 'Impact of underwriter reputation on the accounting conservatism of the IPO firm: South Korean cases', International Journal of Economic Policy in Emerging Economies, 11(3), 238.2 doi: 10.1504/ijepee.2018.10015019

- Institute for World Economy (IWE). 'Brexit: The economic and political impact of a possible withdrawal of Great Britain's from the European Union', [Online], [Retrieved September 10, 2019], http://www.globeco.ro/wpcontent/uploads/vol/split/vol_3n o_2/geo_2015_vol3_no2_art_005.p df

- Jackson, P., (2016), 'Brexit - What Happens to Banking?' [Online], [Retrieved September 10, 2019], https://voxeu.org/article/brexitwhat-happens-banking

- $\quad$ Khalid, B., and Kot, M. (2021), 'The Impact of Accounting Information Systems on Performance Management in the Banking Sector', IBIMA Business Review, Vol. 2021 (2021), Article ID 578902, $10.5171 / 2021.578902$

- Lavery,S. McDaniel, S. and Schmid, D.,(2019), 'Finance fragmented? Frankfurt and Paris as European financial centres after Brexit', Journal of European Public Policy, 26:10, 1502-1520, DOI: 10.1080/13501763.2018.1534876

- Le Roux, C.L., and Saxunová, D., (2020), 'Covid-19 Impact on Stock Indices of Selected EU Countries'. (eds) Delaneville, Novackova, and Saxunova, Business in the European Economic Area - the Present and
Future of EU Integration, number 600433-EPP-1-2018-1-SKEPPJMOMODULE.

- Lightfoot, H., (2016), "The Case for Brexit: a Fallacy that will Put the UK Financial Services at Risk. Global Treasury Intelligence.' [Online], [Retrieved September 10, 2019], https://www.gtnews.com/articles /the-case-for-brexit-a-fallacy-thatwill-put-the-uk-financial-servicessector-at-risk/

- Moran, M., (2021)., 'In the City, the Bluffing Is Over'. [Online], [Retrieved September 7, 2021], https://foreignpolicy.com/2021/0 3/01/london-finance-brexit-jobloss-firms-leaving/

- Morgan McKinley, (2021), 'Summer London Employment Monitor: Roaring Twenties are Back as London's Financial Services Sector Springs into Life.' [Online], [Retrieved September 3, 2021], Retrieved from: https://www.morganmckinley.co $\mathrm{m} / \mathrm{uk} /$ article/summer-londonemployment-monitor-roaringtwenties-are-back-londonsfinancial-services

- Nelson, E., (2021), 'A Week Into Full Brexit, the Pain for U.K. Businesses Has Arrived', [Online], [Retrieved September 12, 2021], https://www.nytimes.com/2021/ 01/09/business/Brexit-Britisheconomy.html

- Novackova, D., Saxunova, D., and Paskrtova, L., (2018), 'Investment aid as a catholicon for regional development in Slovakia?' International Journal of Economic Policy in Emerging Economies, 11(3), 209.2 doi: 10.1504/ijepee.2018.10015018

- OECD, (2021), 'Organisation for Economic Co-operation and Development.' [Online], [Retrieved September 12, 2021], https://data.oecd.org/natincome/ value-added-by-activity.htm

- ONS (2021)., 'Office for National Statistics'. [Online], [Retrieved 
August 24, 2021], https://www.ons.gov.uk/

- Oxenford, M., (2016). 'How would Brexit affect the UK Financial Sector?', Chatham House, International Economics. [Online], [Retrieved September 10, 2019], https://medium.com/@ChathamH ouse/how-would-brexit-affect-theuk-financial-sectorf3f52719e003\#.kmgqfv7jo

- Pricewaterhouse Coopers ,(2016), 'Leaving the EU: Implications for the UK economy', [Online], [Retrieved September 10, 2019], http://www.pwc.co.uk/economicservices/assets/leaving-the-euimplications-for-the-ukeconomy.pdf

- Sako, M., \& Helper, S., (1998), 'Determinants of trust in supplier relations: Evidence from the automotive industry in Japan and in the United States.' Journal of Economic Behavior \& Organization, 34(3), 387-417.

- Saxunova, D., Le Roux, CL and Oster, M., (2019), 'Brexit and its impact on the Financial Sector'. Proceedings of the 34th International-BusinessInformation-ManagementAssociation (IBIMA), ISBN: 978-09998551-3-3, 13-14 November 2019, Madrid, Spain, p. 8658-8668

- Saxunova, D ., Novackova, D., and Bajzikova, L., (2018), " Focus on the Automotive Industry in the Context of a Globalization Process in Slovakia", Journal of Eastern Europe Research in Business and Economics, Vol. 2018 (2018), DOI: 10.5171/2018.435685

- Singh S., Fantazy K., Saxunova D., Lewa, P.M., (2020), 'Impact of Culture, Community, Communications, and Leadership on Social Enterprises Effectiveness in Africa.' (eds) Rajagopal, Behl R. Palgrave Macmillan, Cham DOI:10.1007/978-3-030-230104_20

- The Economist (2014),'The shrinking of British banks is bad for their employees, the City and Britain.', [Online], [Retrieved June 1, 2019], https://www.economist.com/brita in/2014/06/21/now-you-seethem

- $\quad$ Theurer, M., (2016), 'Finanzviertel von London: Brexit-Albträume in Canary Wharf.' [Online], [Retrieved September 17, 2019] http://www.faz.net/aktuell/finanz en/aktien/londoner-finanzviertelcanary-wharf-nach-brexitabstimmung-14312056.html

- Tudorache, M.D., Nae, T.M., and Jianu, I. (2021), 'COVID-19 Pandemic and its Effect on the EU Industry' Journal of EU Research in Business, Vol. 2021 (2021), Article ID 545696, DOI: $10.5171 / 2021.545696$

- Vaghela, V., (2021), 'Amsterdam Is Back Ahead of London as Europe's Top Trading Hub', [Online], [Retrieved September 11, 2021] https://www.bloomberg.com/new s/articles/2021-09-

02/amsterdam-is-back-ahead-oflondon-as-europe-s-top-tradinghub

- Wohl, I., (2016), 'The Impact of Brexit on Financial Services. Executive Briefings on Trade', U.S. International Trade Commission. [Online], [Retrieved September 10, 2019] https://www.usitc.gov/publicatio ns/332/executive_briefings/wohl brexit_and_financial_services_final. pdf 